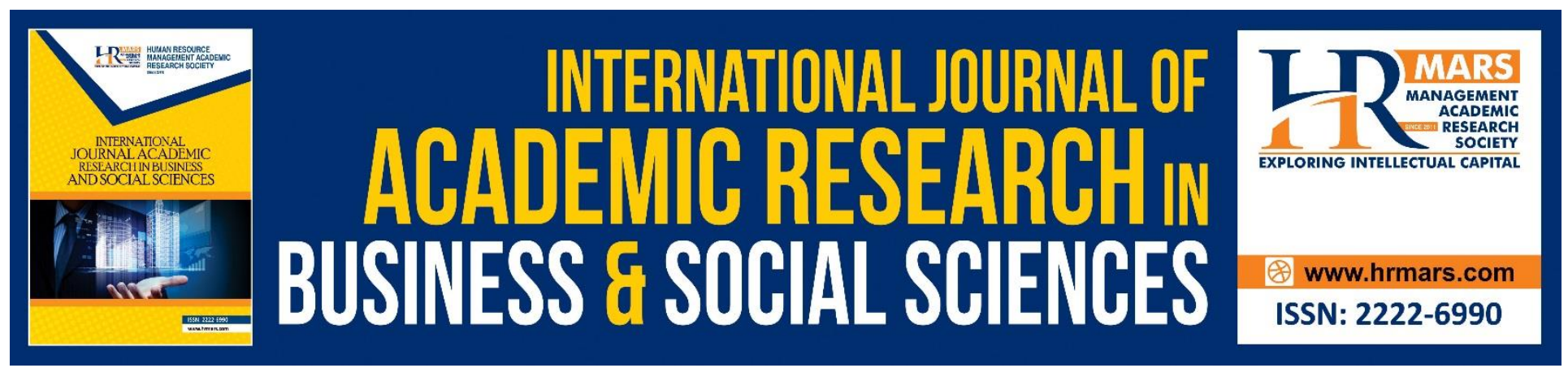

\title{
The Influence of Services Marketing Unit to Satisfaction of Customers in BNI Islamic Bank, Batam Branch-Indonesia
}

Dede Ansyari Guci, Puspa Liza Ghazali and Mustafa Mamat

To Link this Article: http://dx.doi.org/10.6007/IJARBSS/v8-i12/5265

DOI: $10.6007 /$ IJARBSS/v8-i12/5265

Received: 11 Nov 2018, Revised: 19 Dec 2018, Accepted: 02 Jan 2019

Published Online: 08 Jan 2019

In-Text Citation: (Guci, Ghazali, \& Mamat, 2018)

To Cite this Article: Guci, D. A., Ghazali, P. L., \& Mamat, M. (2018). The Influence of Services Marketing Unit to Satisfaction of Customers in BNI Islamic Bank, Batam Branch-Indonesia. International Journal of Academic Research in Business and Social Sciences, 8(12), 1638-1645.

Copyright: (C) 2018 The Author(s)

Published by Human Resource Management Academic Research Society (www.hrmars.com)

This article is published under the Creative Commons Attribution (CC BY 4.0) license. Anyone may reproduce, distribute, translate and create derivative works of this article (for both commercial and non-commercial purposes), subject to full attribution to the original publication and authors. The full terms of this license may be seen at: http://creativecommons.org/licences/by/4.0/legalcode

Vol. 8, No. 12, 2018, Pg. 1638 - 1645

http://hrmars.com/index.php/pages/detail/IJARBSS

JOURNAL HOMEPAGE

Full Terms \& Conditions of access and use can be found at http://hrmars.com/index.php/pages/detail/publication-ethics 


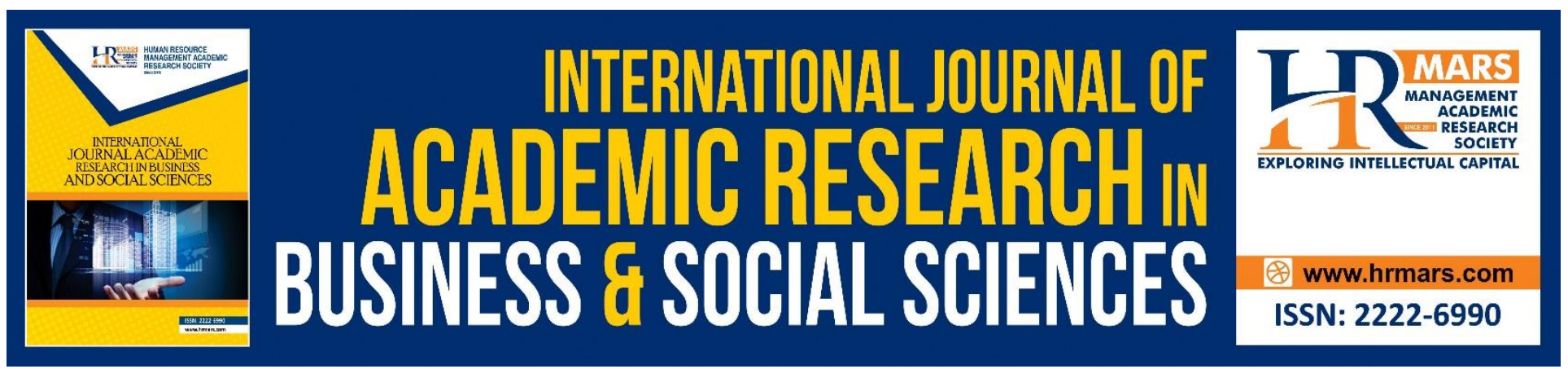

\title{
The Influence of Services Marketing Unit to Satisfaction of Customers in BNI Islamic Bank, Batam Branch-Indonesia
}

\author{
${ }^{1}$ Dede Ansyari Guci, *2Puspa Liza Ghazali and ${ }^{3}$ Mustafa Mamat \\ ${ }^{1}$ Faculty of Economic and Management, Universitas Medan Area. Medan Indonesia. \\ ${ }^{2}$ Faculty of Economic and Management Sciences, Universiti Sultan Zainal Abidin. 21300 Kuala \\ Nerus. Terengganu. Malaysia \\ ${ }^{3}$ Faculty of Informatic and Computer, Universiti Sultan Zainal Abidin. 21300 Kuala Nerus. \\ Terengganu. Malaysia \\ Corresponding Author: puspaliza@unisza.edu.my
}

\begin{abstract}
This study's aim is to examine the influence of services marketing unit to satisfaction of customers in BNI islamic Bank Batam Branch-Indonesia. The data self-collected, using quantitative based-study. Data will be collect by surveyed questionnaire and be analyzed by using Statistical Package for the Social Science (SPSS). The questionnaires distributed were made up of five variables, where four were independent variables and one was dependent variable. By using coeffisient correlation and determinance $\left(R^{2}\right)$, it is found that each independent variable has strong correlation with the single variable. Essentially this research was conducted with seventy five respondents of BNI's customer. Survey was conducted over BNI Islamic Bank Batam Branch, Indonesia. The expected result indicated that speed of process, ease of procedure, clairity of information; friendliness and satisfaction of customers in BNI Islamic Bank Batam Branch-Indonesia have an influence.
\end{abstract}

Keywords: Marketing, Customer Satisfaction, BNI Islamic Bank, Indonesia

\section{Introduction}

Human life in everyday life will not be separated from transaction activity to obtain better benefits than before making a transaction. Transactions that take place in the community can be either goods or services transactions, (Hamid et al., 2018). The marketing system has allowed the transaction process to take place and develop from time to time because marketing is a study that studies the exchange or transactions of how the transaction is initiated, motivated and consumed, (Salleh, Ibrahim, et al., 2018).

Sharia banking is a financial institution that operates in accordance with sharia principles. The begin of sharia banking has had a positive impact in the banking treasures in Indonesia. With the existence of this sharia banking can meet the needs of the community that provides banking services or 
financial institutions are clean of usury and become a better institution, (Noor, Norhayate, Rashid, \& Asyraf, 2018). Banking services have assisted in facilitating exchanges and assisting in the formation of capital for the community (BNI Islamic Bank Company Profile, 2010).

Competition to provide satisfaction in terms of service for customers has placed customers/consumers as decision makers, the more conventional banks that open the unit of sharia by operate service products offered to provide opportunities for the community to make choices in accordance with needs, can be seen in decision making generally influenced by cultural backgrounds that affect the community, with the level of education and knowledge of the higher course of society will be more selective again in taking conclusions to meet the needs of banking, (Alfadhli, Rashid, \& Yaakub, 2018). The people of Indonesia especially the Muslims not only want the services of the right quality but require banking services that do not conflict with Islamic religious principles such as usury (Liu, 2018).

\section{Literature Review}

Marketing is one of the functions of the company that is not less important when compared with the functions of other companies, even the success of the company is often identified with the success of marketing is also used as a benchmark company, but marketing activities are not complete without the functions of other companies such as product, finance and personnel.

According to (Johari, Tarmizi, Mohd, \& Rashid, 2018), marketing is an organizational function and set of processes for creating, communicating and delivering value to customers and managing customer relationships in a way that benefits the organization and its shareholders.

Acording to (Salleh, Noor, et al., 2018), Marketing is a total system of business activities designed to plan, set prices and distribute products, services and ideas that are capable of satisfying the wishes of the target market in order to achieve organizational goals.

Bank is a financial intermediary as a supporting infrastructure that is vital to support the smooth running of the economy. Banks can also be interpreted as a financial institution whose business activities are collecting funds from the community and channeling the funds back into the community and provide other bank services (Usop et al., 2018).

According to (Shams et al., 2018), Bank is business entities that collect funds from the public in the form of savings and channeled into the community in the form of credit and or other forms in order to improve the standard of living of many people.

\section{Methodology}

\section{Examine the Influence of Services Marketing Unit to Satisfaction of Customers in BNI Islamic Bank Batam Branch-Indonesia.}

Based on survey by (Johari et al., 2018) a field study was conducted to examine the influence of services marketing unit to satisfaction of customers in BNI Islamic Bank Batam Branch-Indonesia. 75 questionnaires were distributed in BNI Islamic Bank Batam Branch, Indonesia. Respondents were chosen among loan customer in BNI Islamic Bank Batam Branch. The questionnaire was adopted from (Zain, Abdullah, \& Rashid, 2018). The questionnaire has 2 main parts. First part is demographic profile such as age, number of dependent, level of education and so forth. Second part of the questionnaire is the questions with 5 Likert scale, where 1 is for strongly disagree and 5 for strongly agree. 
INTERNATIONAL JOURNAL OF ACADEMIC RESEARCH IN BUSINESS AND SOCIAL SCIENCES Vol. 8, No. 12, Dec, 2018, E-ISSN: $2222-6990$ C 2018 HRMARS

There are 5 variables under second part due to there are 4 independent variables and 1 independent variable. The 4 independent variables are speed of process, ease of procedure, clairity of information and friendliness. The single independent variable is satisfaction of customers in BNI Islamic Bank Batam Branch-Indonesia. Each variable have 5 item question.

There were 4 hypotheses tested, denoted as $\mathrm{H}_{1}$ to $\mathrm{H}_{4}$, and is listed as in Table 1 below.

Table 1: List of Hypotheses

\begin{tabular}{|l|l|}
\hline & Hypothesis \\
\hline $\mathrm{H}_{1}$ & $\begin{array}{l}\text { Speed of process significantly affects customer satisfaction at BNI Syariah Bank Batam } \\
\text { Branch Office }\end{array}$ \\
\hline $\mathrm{H}_{2}$ & $\begin{array}{l}\text { Ease of procedure significantly affects customer satisfaction at BNI Syariah Bank Batam } \\
\text { Branch Office }\end{array}$ \\
\hline $\mathrm{H}_{3}$ & $\begin{array}{l}\text { Clarity of information significantly affects customer satisfaction at BNI Syariah Bank } \\
\text { Batam Branch Office }\end{array}$ \\
\hline $\mathrm{H}_{4}$ & $\begin{array}{l}\text { Friendliness significantly affects customer satisfaction at BNI Syariah Bank Batam Branch } \\
\text { Office }\end{array}$ \\
\hline
\end{tabular}

As the field study was completed, the responds then entered into Statistical Packages for Social Science (SPSS) version 21.Inferential statistics was adopted and correlation between 4 independent variables and single dependent variable was analyzed. The finding of the field study is presented in result part of this article.

\section{Results}

Before the field study is started, a pilot test was done among 129 respondents. The purpose of conducting the pilot test is to test the reliability of the questionnaire. Below is the reliability analysis result of the pilot test.

Table 2: Reliability Analysis

\begin{tabular}{|l|l|l|}
\hline Variables & Cronbach's Alpha & Number of Items \\
\hline Customer Satisfaction & 0.902 & 5 \\
\hline Speed of Process & 0.892 & 5 \\
\hline Ease of Procedure & 0.897 & 5 \\
\hline Clarity of Information & 0.894 & 5 \\
\hline Friendliness & 0.895 & 5 \\
\hline
\end{tabular}

The result shows that all the variables have higher Cronbach's alpha, where Cronbach's alpha more than 0.6 is considered as acceptable (Rashid et al., 2018). The purpose of checking the Cronbach's alpha is to check the suitability of the adopted instruments to the population and situation of the study.

\section{Normality Test}

Since researchers want to apply inferential statistics in this study, normality test was conducted as its prerequisite (Ismail et al., 2018). By using Kolmogorov-Smoivor statistics, with a Lilliefors significance 
INTERNATIONAL JOURNAL OF ACADEMIC RESEARCH IN BUSINESS AND SOCIAL SCIENCES

Vol. 8, No. 12, Dec, 2018, E-ISSN: 2222-6990 @ 2018 HRMARS

level and Shapiro-Wilk statistics, it shows that the collected data were normally distributed. Table 3 below shows the result.

Table 3: Statistical Normality Test

One-Sample Kolmogorov-Smirnov Test

\begin{tabular}{|c|c|c|}
\hline & & $\begin{array}{l}\text { Unstandardized } \\
\text { Residual }\end{array}$ \\
\hline \multirow[t]{2}{*}{$N$} & & 75 \\
\hline & Mean & .0000000 \\
\hline Normal Parameters ${ }^{a, b}$ & $\begin{array}{l}\text { Std. } \\
\text { Deviation }\end{array}$ & 2.35056836 \\
\hline \multirow{3}{*}{$\begin{array}{ll}\text { Most } & \text { Extreme } \\
\text { Differences } & \end{array}$} & Absolute & .090 \\
\hline & Positive & .086 \\
\hline & Negative & -.080 \\
\hline \multicolumn{2}{|l|}{ Kolmogorov-Smirnov Z } & .901 \\
\hline \multicolumn{2}{|l|}{ Asymp. Sig. (2-tailed) } & .388 \\
\hline
\end{tabular}

a. Test distribution is Normal.

b. Calculated from data.

The $p$-value $(p>0.05)$ on the one-sample Kolmogrov-Smirnov test statistics output on Table 3 shows that the data collected violate the assumption of normality distribution. Due to the violation of normality distribution, (Masud, Daud, Zainol, Rashid, \& Asyraf, 2018) had suggested to use parametric technic technique analysis.

\section{Correlation Result}

Testing the contribution of all independent variables; speed of process (X1), ease of procedure (X2), clarity of information (X3), friendliness (X4), together to the dependent variable of customer satisfaction $(Y)$, can be seen from the coefficient of multiple determination (R2), received: $0<R 2<1$. This indicates if R2 is closer to the value of 1 then the influence of independent variables to the dependent variable the stronger, otherwise if the value of R2 closer to the value of 0 then the influence of independent variables to the independent variable the weaker. The calculation can be seen in table 4 below:

Table 4: $\mathbf{R}^{2}$ test result

Model Summary

\begin{tabular}{|l|l|l|l|l|}
\hline Model & $R$ & R Square & Adjusted R Square & $\begin{array}{l}\text { Std. Error of the } \\
\text { Estimate }\end{array}$ \\
\hline 1 & $.862^{\mathrm{a}}$ & .605 & .666 & 1.32047 \\
\hline
\end{tabular}

a. Predictors: (Constant), KeramahanX4, KemudahanprosedurX2, KecepatanprosesX1, KejelasaninformasiX3

b. Dependent Variable: KepuasannasabahY

Sumber : Data yang diolah dengan SPSS 21 
Based on Table 4 above can be seen that the value of $R=0.862$, means the relationship between variable speed of process, ease of procedure, clarity of information, friendliness towards customer satisfaction at PT. BNI Syariah Bank Batam Branch Office about 86.2\%, means the result indicated that speed of process, ease of procedure, clairity of information, friendliness and satisfaction of customers in BNI Islamic Bank Batam Branch-Indonesia have an influence, in accordance with the criteria in the relationship table between the following variables as assume in the table 5 below:

Tabel 5: Relationship among Variable

\begin{tabular}{|l|l|}
\hline Nilai & Interprestasi \\
\hline $0.0-0.19$ & Very Weak \\
\hline $0.2-0.39$ & Weak \\
\hline $0.4-0.59$ & Average \\
\hline $0.6-0.79$ & Strong \\
\hline $0.8-0.99$ & Very Strong \\
\hline
\end{tabular}

Source: Sugiono [2010]

\section{Conclusion}

From the correlation result, it can be concluded that speed of process, ease of procedure, clairity of information, friendliness and satisfaction of customers in BNI Islamic Bank Batam Branch-Indonesia have an influence. Speed of process, ease of procedure, clarity information and friendliness correlated to customer satisfaction means strong, significance and unidirectional, means that customer satisfied with the service of BNI Islamic Bank Batam Branch-Indonesia (Musibau et al., 2018).

\section{References}

Alfadhli, M. I., Rashid, N., \& Yaakub, N. (2018). The Impact of Internal Audit and its Quality on Sales in Economic Institutions: A Case Study ( Al-Ahlia Cement Company - Libya ) The Impact of Internal Audit and its Quality on Sales in Economic Institutions : A Case Study ( Al-Ahlia Cement Company - Lib. International Journal of Academic Research in Business and Social Sciences, 8(8), 50-65. https://doi.org/10.6007/IJARBSS/v8-i8/4434

Hamid, N. A., Aisyah, H., Taib, M., Noor, R., Yaacob, Z., Shamsuddin, R., ... Afthanorhan, A. (2018). The Effect of Tax Reforms on Tax Agents ' Job Burnout in Malaysia The Effect of Tax Reforms on Tax Agents ' Job Burnout in Malaysia. International Journal of Academic Research in Business and Social Sciences, 8(12), 547-560. https://doi.org/10.6007/IJARBSS/v8-i12/5054

Ismail, M., Zainol, F. A., Norhayate, W., Daud, W., Rashid, N., \& Afthanorhan, A. (2018). Application of Entrepreneurial Marketing to the Marketing Mix : Why it Matters to SMEs in Malaysia ? Application of Entrepreneurial Marketing to the Marketing Mix : Why it Matters to SMEs in Malaysia ? International Journal of Academic Research in Business and Social Sciences, 8(12), 850-865. https://doi.org/10.6007/IJARBSS/v8-i12/5079

Johari, R. J., Tarmizi, M., Mohd, H., \& Rashid, N. (2018). A Revisited Note on Internal Audit Function and Good Corporate Governance A Revisited Note on Internal Audit Function and Good Corporate Governance. International Journal of Academic Research in Business and Social 
INTERNATIONAL JOURNAL OF ACADEMIC RESEARCH IN BUSINESS AND SOCIAL SCIENCES

Vol. 8, No. 12, Dec, 2018, E-ISSN: 2222-6990 @ 2018 HRMARS

Sciences, 8(12), 716-728. https://doi.org/10.6007/IJARBSS/v8-i12/5067

Liu, S. (2018). Earnings management and institutional investor trading prior to earnings announcements. China Finance Review International, CFRI-01-2018-0010. https://doi.org/10.1108/CFRI-01-2018-0010

Masud, H., Daud, W. N. W., Zainol, F. A., Rashid, N., \& Asyraf, A. (2018). A critique of normative commitment in management research. International Journal of Academic Research in Business and Social Sciences, 8(11), 1172-1191. https://doi.org/10.6007/IJARBSS/v8-i11/5161

Musibau, H. O., Mahmood, S., Ismail, S., Shamsuddin, Z., Rashid, N., \& Mahmood, S. (2018). Does External Debt Cause Economic Growth ? An Experience from ECOWAS Member Countries Does External Debt Cause Economic Growth ? An Experience from ECOWAS Member Countries. International Journal of Academic Research in Business and Social Sciences, 8(11), 1256-1264. https://doi.org/10.6007/IJARBSS/v8-i11/5167

Noor, N., Norhayate, W., Rashid, N., \& Asyraf, A. (2018). Exploring the Predominant Qualities of Head Teachers towards Achieving School Success Exploring the Predominant Qualities of Head Teachers towards Achieving School Success. International Journal of Academic Research in Business and Social Sciences, 8(11), 1324-1330. https://doi.org/10.6007/IJARBSS/v8-i11/5173

Rashid, N., Zainol, F. A., Salleh, F., Endut, W. A., Yaakub, N., Ghazali, P. L., ... Daud, W. N. W. (2018). Quality of Financial Reporting towards the Improvement Corporate Governance Mechanism Quality of Financial Reporting towards the Improvement Corporate Governance Mechanism. International Journal of Academic Research in Business and Social Sciences, 8(11), 1339-1345. https://doi.org/10.6007/IJARBSS/v8-i11/5175

Salleh, F., Ibrahim, M. D., Yazid, A. S., Afthanorhan, A., Rashid, N., \& Ghazali, P. L. (2018). Micro Small and Medium Enterprise Demand for General Takaful : Proposed Theoretical Framework and Hypotheses Development Micro Small and Medium Enterprise Demand for General Takaful : Proposed Theoretical Framework and Hypotheses Development. International Journal of Academic Research in Business and Social Sciences, 8(12), 599-612. https://doi.org/10.6007/IJARBSS/v8-i12/5058

Salleh, F., Noor, D., Ag, H., Yazid, A. S., Salleh, F., Noor, D., ... Rashid, N. (2018). Consumer Behaviour and Insurance Claim Fraud in Malaysia Consumer Behaviour and Insurance Claim Fraud in Malaysia. International Journal of Academic Research in Business and Social Sciences, 8(12), 586-598. https://doi.org/10.6007/IJARBSS/v8-i12/5057

Shams, A., Hoque, M. M., Awang, Z. Bin, Muda, H., Salleh, F., \& Rashid, N. (2018). Ramification of crowdfunding on Bangladeshi entrepreneur's self-efficacy. International Journal of Academic Research in Business and Social Sciences, 8(12), 129-138.

https://doi.org/10.5267/j.ac.2018.04.001

Usop, R., Zainol, F. A., Chik, Z., Norhayate, W., Daud, W., Rashid, N., \& Afthanorhan, A. (2018). Competitive Advantage and Performance : Empirical Investigation on Demographic Factors of Malaysian Hotel Entrepreneurs Competitive Advantage and Performance : Empirical Investigation on Demographic Factors of Malaysian Hotel Entrepreneurs. International Journal of Academic Research in Business and Social Sciences, 8(12), 810-819.

https://doi.org/10.6007/IJARBSS/v8-i12/5067

Zain, F. A. M., Abdullah, W. A. W., \& Rashid, N. (2018). The Mediating Role of Environmental 
INTERNATIONAL JOURNAL OF ACADEMIC RESEARCH IN BUSINESS AND SOCIAL SCIENCES

Vol. 8, No. 12, Dec, 2018, E-ISSN: 2222-6990 @ 2018 HRMARS

Performance on The Relationship Between Corporate Governance Mechanisms and

Environmental Disclosure. Asian Academy of Management Journal of Accounting and Finance, 14(1), 153-183. https://doi.org/10.21315/aamjaf2018.14.1.7 